\title{
Mycofumigation with Muscodor albus and Muscodor roseus for Control of Seedling Diseases of Sugar Beet and Verticillium Wilt of Eggplant
}

\author{
A. M. Stinson, N. K. Zidack, G. A. Strobel, and B. J. Jacobsen, Department of Plant Science and Plant Pathol- \\ ogy, Montana State University, Bozeman 59717-3150
}

\begin{abstract}
Stinson, A. M., Zidack, N. K., Strobel, G. A., and Jacobsen, B. J. 2003. Mycofumigation with Muscodor albus and Muscodor roseus for control of seedling diseases of sugar beet and Verticillium wilt of eggplant. Plant Dis. 87:1349-1354.

Mycofumigation is the use of antimicrobial volatiles produced by fungi such as Muscodor albus and M. roseus for the control of other organisms. Sugar beet (Beta vulgaris L.) stand establishment was increased and disease severity decreased by mycofumigation with $M$. roseus and $M$. albus in autoclaved soil infested with Rhizoctonia solani, Pythium ultimum, or Aphanomyces cochlioides. Eggplant seedlings (Solanum melongena L.) transplanted into autoclaved soil infested with Verticillium dahliae and mycofumigated with M. albus and M. roseus had significantly less disease $(P<0.05)$ after 4 and 5 weeks compared with nonmycofumigated Verticillium-infested soil. The effect of formulation on efficacy of mycofumigation with $M$. roseus was tested using potato dextrose agar strips, alginate capsules, ground barley, pesta granules, and stabileze granules. The stabileze and ground barley formulations of $M$. roseus resulted in the best control of $P$. ultimum damping-off. The best control of $A$. cochlioides damping-off was with the stabileze formulation, and the stabileze, ground barley, and agar strip formulations provided similar control of $R$. solani damping-off. In soil infested with $P$. ultimum, mycofumigation with $M$. albus stabileze formulation resulted in stand establishment similar to that in the autoclaved soil. Mycofumigation was ineffective in controlling Fusarium wilt of sugar beet. Neither $M$. albus nor M. roseus affected sugar beet or eggplant growth or appearance except in the stabileze formulation, where stunting was noticed. Mycofumigation with $M$. albus and M. roseus shows promise for control of soilborne diseases caused by P. ultimum, A. cochlioides, $R$. solani, and $V$. dahliae.
\end{abstract}

Additional keywords: biological control

This research introduces "mycofumigation" as an alternative concept for the biological control of soilborne pathogens. Mycofumigation refers to the use of antimicrobial volatiles produced by fungi, including the endophytic fungi Muscodor albus (isolate 620) (24) and Muscodor roseus (isolate A3-5) (23) for the control of microorganisms. In vitro effects of mycofumigant gases produced by Trichoderma spp. and $M$. albus have been described by Dennis and Webster (7) and Strobel et al (21), respectively. Strobel et al. (21) identified five classes of compounds (alcohols, esters, ketones, acids, and lipids) as the key components of the mycofumigant gas volatiles. The compounds within each class

Corresponding author: B. J. Jacobsen E-mail: uplbj@montana.edu

This research has been supported by USDA/CSREES Methyl Bromide Alternatives grant \# 2001-51102-11338. This article has been assigned journal paper \#2003-3 by the Montana Agricultural Experiment Station.

Accepted for publication 20 June 2003.

Publication no. D-2003-0829-01R

(c) 2003 The American Phytopathological Society were tested individually and combined into an artificial mixture in vitro for biological activity against Pythium ultimum, Rhizoctonia solani, Phytophthora cinnamoni, Verticillium dahliae, Fusarium oxysporum f. sp. betae, and Sclerotinia sclerotiorum (21). No single chemical class was as toxic independently to test fungi as the natural volatiles from $M$. albus. The combination of synthetic gas components, however, were equally toxic to test microbes, indicating an additive or synergistic effect among the classes of volatiles. The most effective single component was the esters (21). Volatile compounds produced by $M$. albus killed all test fungi except $F$. $o x$ ysporum f. sp. betae after 3 days of exposure. Fusarium oxysporum f. sp. betae was only inhibited.

Management of soilborne pathogens is a major reason for the use of soil fumigants. Annual agricultural use of the broad-spectrum pesticide methyl bromide in the United States totals about 19,000 metric tons, with soil fumigation accounting for $85 \%$ of the total use (27). For over 20 years, preplant soil fumigation with methyl bromide-chloropicrin (MBC) has been the standard method used by strawberry growers to prevent weed and soilborne pest and disease problems (4). Due to its implica- tions in ozone depletion, methyl bromide is scheduled to be phased out by the year 2005 in developed countries and 2025 in developing countries (27). Currently, both chemical and nonchemical alternatives to methyl bromide are being investigated for management of soilborne pathogens (8). Chemical alternatives include chloropicrin, iodomethane, 1,3-dichloropropene + chloropicrin (Telone C-35), metam sodium (Vapam), dazomet (Basmid), and various combinations of the above products with sodium tetrathiocarbamate (Enzone) (15).

Nonchemical alternatives to soil fumigation with methyl bromide include crop rotation, solarization (5), biofumigation with Brassica spp. $(2,5,18,20)$, and incorporation of organic composts or biological controls (9). Solarization is not a practical alternative in most temperate climates and is highly weather dependent. Regions where high summer temperatures coincide with rainy seasons, such as the southeastern United States, may have less potential for successful solarization because of the cooling effect of frequent rain showers and the extended cloud cover reduces solar radiation captured under the plastic tarp (5). However, none of these have proven to be acceptable replacements for methyl bromide + chloropicrin in all environments. This research explores the potential for $M$. albus or $M$. roseus as an alternative for control of soilborne plant pathogenic fungi.

The objective of this research was to determine if the mycofumigant effects of $M$. albus or $M$. roseus observed on phytopathogenic fungi in vitro in petri plate assays could be effectively transferred to in vivo assays using sugar beet (Beta vulgaris L.) and eggplant (Solanum melongena L.) pathosystems and infested soil. The sugar beet pathosystem was selected because assay protocols were established in our lab, and eggplant was selected because of its susceptibility to $V$. dahliae and because it develops symptoms rapidly in the glasshouse. Pythium ultimum, Aphanomyces cochlioides, $R$. solani, $F$. oxysporum f. sp. betae, and $V$. dahliae were chosen as test pathogens because they are ubiquitous soil inhabitants with resistant survival structures and are representative of the pathogens controlled through preplant soil fumigation with MBC mixtures. P. ultimum, A. cochlioides, and $R$. solani commonly result in damping off of seedlings and root rot. $F$. oxysporum f. sp. betae and V. dahliae are 
responsible for causing systemic vascular wilts in sugar beet and eggplant, respectively.

The effects of mycofumigation on disease incidence and severity, population densities of $V$. dahliae, and the growth of sugar beet seedlings are reported here. Five different formulations of $M$. roseus were evaluated as mycofumigants.

\section{MATERIALS AND METHODS}

Inoculum production of phytopathogenic fungi. $R$. solani AG 2-2 and a chlorate-resistant nitrate-nonutilizing (nit) mutant (11) of $V$. dahliae (provided by $\mathrm{R}$. Rowe, Ohio State University) inoculum was produced by transferring these fungi separately from potato dextrose agar (PDA) cultures to sterile, moist whole barley grains in 1-liter Erlenmeyer flasks $(16,19)$. The inoculated barley was kept at $23 \pm 1^{\circ} \mathrm{C}$ and shaken every day during a 2week incubation period, followed by air drying at $23 \pm 1^{\circ} \mathrm{C}$ for $48 \mathrm{~h}$. Inoculum was ground to a sawdust texture (30 to 1,500 $\mu \mathrm{m}$, with a mean particle size of approximately $300 \mu \mathrm{m}$ ) with a Waring blender. Inoculum was stored at $4^{\circ} \mathrm{C}$ for up to 9 months. Inoculum consisted primarily of sclerotia, microsclerotia, and dormant mycelium. Two different inoculum batches (A and $\mathrm{B}$ ) of $R$. solani were produced as described above were used as inoculum. Batch $B$ resulted in an increased amount of disease when used at the same inoculum level as batch A, even through they were produced under the same conditions and from the same stock culture. P. ultimum and $A$. cochlioides were grown in $9-\mathrm{cm}-$ diameter petri dishes on PDA at $23^{\circ} \mathrm{C}$ until the agar surface was covered. The resulting colonized agar contained mycelia, sporangia and oospores. F. oxysporum f. sp betae was grown in potato dextrose broth (PDB) on a shaker at room temperature $(23 \pm$ $1^{\circ} \mathrm{C}$ ) for 2 weeks. Inoculum was primarily microconidia and chlamydospores.

Preparation of mycofumigant. $M$. albus and $M$. roseus was applied as colonized agar strips, ground pesta, and alginate formulations and in the stabileze formulation. M. albus and $M$. roseus were grown in 9-cm-diameter petri plates of PDA at $23 \pm 1{ }^{\circ} \mathrm{C}$ for 2 weeks. Four agar strips $(0.5$ by 8.0 by $0.5 \mathrm{~cm})$ per $375 \mathrm{~g}$ of soil were used as agar strip inoculum. For the initial formulation trial, $M$. roseus was grown in $250 \mathrm{ml}$ of PDB, after which the following formulations were prepared: pesta, a formulation including semolina flour and kaolin clay (6); alginate capsules, composed of sodium alginate and kaolin clay (22); and stabileze, a mixture of water-absorbent starch, corn oil, sucrose, and fumed silica (17). Pesta and alginate formulations were ground in a Waring blender to a particle size of approximately 1 to 2 $\mathrm{mm}$. The formulations were dried under the hood for 48 to $72 \mathrm{~h}$ and stored at $4^{\circ} \mathrm{C}$. The stabileze formulation was prepared in a small food processor, resulting in granules 0.5 to $2 \mathrm{~mm}$ in size. Excess silica was removed from the stabileze formulation using a $500-\mu \mathrm{m}$ sieve, retaining the material on the top of the sieve for use. $M$. roseus also was grown on barley following the protocol previously described for $R$. solani and V. dahliae. M. albus was grown in $250 \mathrm{ml}$ of PDB on a shaker for 2 weeks, then prepared using the stabileze formulation (17). CFU per gram of the stabileze formulation were estimated by adding 0.1 $\mathrm{g}$ of stabileze formulation to $9 \mathrm{ml}$ of $0.1 \%$ agar, serially diluting the suspension, and culturing 1-ml aliquots on PDA supplemented with streptomycin sulfate at 30 $\mu \mathrm{g} / \mathrm{ml}$ and tetracycline at $12 \mu \mathrm{g} / \mathrm{ml}$. Plates were incubated in a plastic box at $23^{\circ} \mathrm{C}$ for 5 days, after which colonies were counted. To determine whether the colonized barley or stabilize inoculum had antifungal activity, they were autoclaved and placed on petri plates containing PDA with 5-mm $P$. ultimum or $R$. solani plugs for 7 days, at which time colony growth was compared with nonamended plates.

Soil infestation and greenhouse bioassay. Greenhouse bioassays were conducted in a steam-pasteurized $\left(80^{\circ} \mathrm{C}\right.$ for $\left.30 \mathrm{~min}\right)$ potting mix containing equal parts of Bozeman silt loam soil:washed concrete sand and Canadian sphagnum peat moss (vol/vol). AquaGro 2000G wetting agent was blended in at $2.2 \mathrm{~kg}$ per $0.078 \mathrm{~m}^{3}$ of soil mix. The potting mix was then screened through a 2-mm mesh sieve and autoclaved for $75 \mathrm{~min}$. Ground barley inoculum was thoroughly mixed at 5 and 2.5 $\mathrm{g}$ of inoculum $/ \mathrm{kg}$ of soil for $R$. solani and $V$. dahliae, respectively. Initial inoculum levels of $V$. dahliae were estimated by dilution plating on selective media consisting of $2 \%$ water agar, $0.2 \%$ glucose, and potassium chlorate at $25 \mathrm{~g} / \mathrm{liter}$ (12) supplemented with streptomycin sulfate at 30 $\mu \mathrm{g} / \mathrm{ml}$ and tetracycline at $12 \mu \mathrm{g} / \mathrm{ml}$ to control bacterial contamination. P. ultimumand A. cochlioides-colonized agar was homogenized in a Handy Chopper (Black and Decker, Chicago) and mixed at a rate of 1 petri plate/6.4 $\mathrm{kg}$ of soil. Soil was infested with $F$. oxysporum f. sp. betae by mixing $1 \mathrm{ml}$ of liquid culture per $375 \mathrm{~g}$ of soil. Initial and 1-week-after-fumigation inoculum levels were estimated by soil dilution on Nash-Snyder (14) medium.

The experimental design was a randomized complete block with five replications of the following treatments: untreated control (UTC), pathogen only, pathogen plus $M$. albus, and pathogen plus $M$. roseus. Each treatment replication consisted of a square pot $(10$ by 10 by $8.6 \mathrm{~cm}$ ) lined with a paper towel. In the controls (untreated, pathogen only) $375 \mathrm{~g}$ of autoclaved soil was added per pot. For M. albus and $M$. roseus treatments, $325 \mathrm{~g}$ of pathogeninfested soil was added, either four agar strips $(0.5$ by 8.0 by $0.5 \mathrm{~cm})$ or $2 \mathrm{~g}$ of the other mycofumigant formulations spread uniformly in a layer, then covered with 50 $\mathrm{g}$ of pathogen-infested soil. Each pot was placed in a 3.78-liter plastic bag containing $100 \mathrm{ml}$ of water and the bag was twist tied. The treatments then were stored in a dark room at $23 \pm 1^{\circ} \mathrm{C}$ for 1 week to complete the mycofumigation process. Then, 25 untreated Beta 8754 sugar beet (B. vulgaris L.) seed were planted into each pot. The pots were placed in a greenhouse at day and night temperatures of 22 and $18^{\circ} \mathrm{C}$, respectively (16-h photoperiod). Pots treated with $P$. ultimum and $A$. cochlioides were placed in shallow saucers with standing water for 3 days immediately after planting to favor infection. Percent seedling emergence was recorded at 7 and 14 days after planting and final stand 1 week later. Individual seedlings then were removed and the roots were washed and rated for disease severity with a disease index (DI) calculated from the formula DI $=[\Sigma$ (number of plants in each severity class $\times$ class number $)] \times 100 /($ mean number of plants grown in autoclaved soil $x$ number of disease classes). Seedling disease severity classes used were $0=$ healthy, $1=$ root or hypocotyls discolored, $2=$ root or hypocotyls rotted but top green, and $3=$ seedlings dead.

For eggplant disease assays, 3-week-old eggplant (cv. Black Beauty) seedlings were transplanted into pots (1 per pot) containing soil infested with $V$. dahliae at 0 and $1.64 \times 10^{4} \mathrm{CFU} / \mathrm{g}$ of oven-dry soil. Infested soil was sampled to determine $\mathrm{CFU} / \mathrm{g}$ before and after the 1-week fumigation period. $V$. dahliae populations were determined by placing $1 \mathrm{~g}$ of soil into $9 \mathrm{ml}$ of $0.1 \%$ agar; the soil solution then was vortexed for $45 \mathrm{~s}$, then poured through one layer of cheesecloth. Three replicates of each dilution were plated per treatment. The plates were stored in a $24^{\circ} \mathrm{C}$ incubator for 7 days and colonies were counted. The same plates were read again at 10 days to be sure all CFU were counted. The transplanted eggplant seedlings were observed weekly and a DI calculated for each treatment. The DI was based on a scale of 0 to 3 , where $0=$ symptoms absent; $1=$ symptoms slight, may have small areas of chlorosis, transplant not stunted; $2=$ symptoms moderate, leaves yellowing, partial wilt of a couple of leaves, slightly stunted; and $3=$ complete wilt, all leaves affected, and transplant severely stunted. DI was calculated using the previously mentioned DI formula.

All experiments were conducted two or three times with similar results and data presented represents pooled experiments. Data was analyzed by analysis of variance using the general linear model procedure of SAS and means were separated using Fisher's least significant difference test.

\section{RESULTS}

In repeated experiments designed to test the effect of mycofumigation by $M$. albus 
and $M$. roseus on sugar beet emergence and growth, no effect on sugar beet emergence or plant appearance was observed when compared with emergence and appearance of seedlings in nonmycofumigated autoclaved soil, except where the stabileze formulation was used (data unpublished). Stunting was noted whenever this formulation was used. When M. albus or M. roseus ground barley or stabilize formulations were tested in agar plate assays after autoclaving, no growth reductions were noted for either P. ultimum or R. solani compared with total growth inhibition when nonautoclaved formulations were used.

Influence of mycofumigation on seedling diseases. In $R$. solani-infested soil, mycofumigation with $M$. roseus formulated as agar strips, ground barley, or stabileze formulations resulted in stand establishment greater than the pathogen control, and only the ground barley formulation was similar to that observed in the autoclaved soil (Table 1). The pesta and alginate formulations were less effective and were dropped from further consideration after initial experiments.

In $P$. ultimum-infested soil, none of the mycofumigant treatments resulted in stand establishment similar to that in the autoclaved soil. Mycofumigation with $M$. roseus formulated as stabileze, ground barley, and agar strips, however, resulted in greater stand establishment than that in nonmycofumigated $P$. ultimum-infested soil (Table 1). Mycofumigation with $M$. roseus formulated as pesta granules was not effective and was dropped from consideration after initial experiments.

In soil infested with $A$. cochlioides, none of the mycofumigant formulation treatments resulted in stand establishment similar to that in the autoclaved soil. Mycofumigation with $M$. roseus formulated as stabileze and ground barley, however, resulted in greater stand establishment than that in nonmycofumigated Aphanomyces spp.-infested soil. The stabileze formulation resulted in greater stand establishment than the ground barley formulation (Table 1).

These experiments showed that the $M$. roseus stabileze formulation resulted in the best control of A. cochlioides, and was equal to mycofumigation with $M$. roseus ground barley formulation in $R$. solaniand $P$. ultimum-infested soil; therefore, additional experiments were designed for the stabileze formulation. Although emergence was similar, plants grown in soil mycofumigated using the stabileze formulation were smaller (data not shown).

Efficacy of $M$. roseus and $M$. albus stabileze formulation for mycofumigation. In soil infested with $R$. solani, mycofumigation with $M$. albus and $M$. roseus resulted in lower $(P<0.05)$ stand establishment than that in autoclaved soil. Mycofumigation with $M$. albus and $M$. roseus, however, did result in greater stand estab- lishment than that in $R$. solani-infested soil. Mycofumigation with M. albus resulted in significantly greater stand establishment than mycofumigation with $M$. roseus. Seedlings grown in $R$. solaniinfested soil mycofumigated with $M$. albus showed less disease than those grown in soil mycofumigated with $M$. roseus. Neither mycofumigation treatment resulted in a DI similar to the DI of seedlings grown in autoclaved soil (Table 2).

In soil infested with $P$. ultimum, mycofumigation with $M$. albus resulted in stand establishment similar to that in the autoclaved soil (Table 2). Mycofumigation of P. ultimum-infested soil with $M$. roseus did not result in stand establishment similar to that in the autoclaved soil; however, stand establishment was greater than that in nonmycofumigated $P$. ultimum-infested soil. Mycofumigation with $M$. roseus resulted in stand establishment similar to that in soil mycofumigated with M. albus (Table 2). Seedlings in soil mycofumigated with $M$. albus and M. roseus had similar DIs, which were lower than the DI of seedlings grown in nonmycofumigated $P$. ultimum-infested soil. Neither mycofumigation treatment resulted in a DI similar to the DI of seedlings grown in autoclaved soil (Table 2).

Mycofumigation of $A$. cochlioides-infested soil with $M$. albus and $M$. roseus resulted in stand establishment lower than that in the autoclaved soil; however, myco- fumigation with $M$. albus resulted in a greater stand establishment than that in nonmycofumigated $A$. cochlioides-infested soil or infested soil mycofumigated with $M$. roseus. (Table 2). Seedlings grown in soil mycofumigated with $M$. albus had a lower DI when compared with the DI of seedlings grown in nonmycofumigated $A$. cochlioides-infested soil. Seedlings grown in A. cochlioides-infested soil mycofumigated with $M$. roseus had a DI similar to that of seedlings grown in M. albus-mycofumigated soil (Table 2).

Mycofumigation of $F$. oxysporum f. sp. betae-infested soil for 1 week with $M$. albus and M. roseus resulted in 292 and $116 \mathrm{CFU}$, respectively, of $F$. oxysporum $\mathrm{f}$. sp. betae per gram of soil, compared with nonfumigated soil with $120 \mathrm{CFU} / \mathrm{g}$ of soil. These levels were not significantly different at $P=0.1$. Disease severity indexes were 56.6 and 61.9 for $M$. albus and $M$. roseus, respectively, and 66.2 for nonmycofumigated infested soil. These differences were not significantly different at $P$ $=0.1$.

The effect of mycofumigation with $M$. albus and $M$. roseus on inoculum of $V$. dahliae was highly variable (coefficient of variation 310.4 ). In soil initially infested with $V$. dahliae at $1.64 \times 10^{4} \mathrm{CFU} / \mathrm{g}$ of soil, mycofumigation with $M$. albus resulted in a population statistically equal to autoclaved soil. Mycofumigation with $M$.

Table 1. Percent survival of sugar beet 21 days after planting into autoclaved soil infested with Rhizoctonia solani AG 2-2, Pythium ultimum, or Aphanomyces cochlioides, compared with infested soil mycofumigated for 7 days with ground barley, stabileze, and agar strip formulations of $M u s$ codor roseus

\begin{tabular}{lccc}
\hline & \multicolumn{3}{c}{ Pathogen used to infest soilz } \\
\cline { 2 - 4 } Treatment & R. solani & P. ultimum & A. cochlioides \\
\hline Noninfested autoclaved control & $90.0 \mathrm{a}$ & $81.8 \mathrm{a}$ & $86.8 \mathrm{a}$ \\
Pathogen-infested control & $40.4 \mathrm{~d}$ & $20.8 \mathrm{c}$ & $10.7 \mathrm{~d}$ \\
M. roseus ground barley & $80.4 \mathrm{ab}$ & $61.3 \mathrm{~b}$ & $20.4 \mathrm{c}$ \\
M. roseus stabileze & $75.0 \mathrm{~b}$ & $60.0 \mathrm{~b}$ & $30.4 \mathrm{~b}$ \\
$M$. roseus agar strips & $73.6 \mathrm{~b}$ & $49.2 \mathrm{~b}$ & $\mathrm{ND}$
\end{tabular}

z Soil was infested as follows: $R$. solani, $5 \mathrm{~g}$ of dry ground barley inoculum $/ \mathrm{kg}$ of soil; P. ultimum and $A$. cochlioides, one homogenized, completely colonized $10-\mathrm{cm}$ petri plate $/ 6.4 \mathrm{~kg}$ of soil. Means followed by the same letter are not significantly different at $P<0.05$. Each value is the mean of three experiments with five replicates in each experiment. There was no treatment-experiment interaction. $\mathrm{ND}=$ not done.

Table 2. Percent seedling survival and disease index (DI) of sugar beet 21 days after planting into nonmycofumigated sterilized soil infested with Rhizoctonia solani AG 2-2, Pythium ultimum, and Aphanomyces cochlioides, compared with infested soil mycofumigated for 7 days with Muscodor albus or $M$. roseus in the stabileze formulation ${ }^{\mathrm{z}}$

\begin{tabular}{|c|c|c|c|c|c|c|}
\hline \multirow[b]{2}{*}{ Treatment } & \multicolumn{2}{|c|}{ R. solani } & \multicolumn{2}{|c|}{ P. ultimum } & \multicolumn{2}{|c|}{ A. cochlioides } \\
\hline & Stand (\%) & DI & Stand (\%) & DI & Stand (\%) & DI \\
\hline Noninfested control & 96 a & $0 \mathrm{~d}$ & 88.8 a & $0 \mathrm{c}$ & $78.4 \mathrm{a}$ & $0 \mathrm{c}$ \\
\hline Pathogen infested control & $8.8 \mathrm{~d}$ & $68.3 \mathrm{a}$ & $14.4 \mathrm{c}$ & $76.4 \mathrm{a}$ & $13.6 \mathrm{c}$ & $82.6 \mathrm{a}$ \\
\hline M. roseus stabileze & $31.2 \mathrm{c}$ & $47.7 \mathrm{~b}$ & $73.6 \mathrm{~b}$ & $24.1 \mathrm{~b}$ & $29.6 \mathrm{bc}$ & $69.1 \mathrm{ab}$ \\
\hline M. albus stabileze & $63.2 \mathrm{~b}$ & $28.5 \mathrm{c}$ & $76.8 \mathrm{ab}$ & $26.8 \mathrm{~b}$ & $45.6 \mathrm{~b}$ & $55.1 \mathrm{~b}$ \\
\hline
\end{tabular}

zeans followed by the same letter are not significantly different at $P<0.05$. Each value is the mean of five replicates from two experiments. There was no treatment-experiment interaction. DI was based on a scale of 0 to 3 , where $0=$ healthy, $1=$ root or hypocotyls discolored, $2=$ root or hypocotyls rotted but seedling still green, and $3=$ seedling dead. DI was calculated using the following formula: $\mathrm{DI}=[\Sigma($ number of plants in each severity class $\times$ class number $)] \times 100 /($ mean number of plants grown in autoclaved soil $\times$ number of disease classes). 
roseus resulted in populations statistically similar to nonmycofumigated $V$. dahliaeinfested soil (Table 3). However, the DI was significantly lower for eggplant growing in mycofumigated soil compared with eggplant growing in nonmycofumigated $V$. dahliae-infested soil after 4 and 5 weeks (Table 3). The DI of the eggplant grown in soil mycofumigated with $M$. albus and $M$. roseus was statistically similar to the DI of eggplant growing in autoclaved soil after 4 weeks. At 5 weeks, only plants grown in $M$. albus-mycofumigated, $V$. dahliaeinfested soil had a DI similar to that of plants grown in autoclaved soil (Table 3; Fig. 1). After 5 weeks, the DI of eggplant growing in soil mycofumigated with $M$. roseus was statistically equal to that of $M$. albus-mycofumigated plants but higher than that of plants grown in autoclaved soil.

\section{DISCUSSION}

Mycofumigation with $M$. albus and $M$. roseus was effective in reducing disease severity associated with the soilborne plant pathogens: R. solani, P. ultimum, A. cochlioides, and $V$. dahliae. The percent stand establishment of sugar beet seedlings in treatments using $M$. albus was consistently greater and the DI was lower relative to the nonmycofumigated pathogen-infested soil. Neither $M$. roseus nor $M$. albus reduced soil populations of $F$. oxysporum f. sp. betae or disease severity caused by this fungus. This was consistent with in vitro tests, which showed only inhibitory but nonlethal effects of the mycofumigant gas on F. oxysporum f. sp. betae (21).

In the initial experiments with $R$. solani and $M$. roseus (Table 1), stand establishment in the $R$. solani-infested soil treatment at 3 weeks after planting the seed was

Table 3. Verticillium dahliae soil population (CFU/g of dry soil) after infested soil was mycofumigated for 7 days by either Muscodor albus or M. roseus using the stabileze formulation, compared with nonmycofumigated soil ${ }^{\mathrm{z}}$

\begin{tabular}{lccc}
\hline Treatment & Population (CFU/g) & DI (4 weeks) & DI (5 weeks) \\
\hline Autoclaved, noninfested control & $0 \mathrm{~b}$ & $0.0 \mathrm{~b}$ & $0.0 \mathrm{c}$ \\
V. dahliae & $66,840 \mathrm{a}$ & $55.0 \mathrm{a}$ & $60.0 \mathrm{a}$ \\
V. dahliae + M. roseus & $21,438 \mathrm{ab}$ & $17.5 \mathrm{~b}$ & $32.5 \mathrm{~b}$ \\
V. dahliae + M. albus & $1,257 \mathrm{~b}$ & $10.0 \mathrm{~b}$ & $20.0 \mathrm{bc}$ \\
\hline
\end{tabular}

${ }^{\mathrm{z}}$ Initial population of $V$. dahliae was $1.64 \times 10^{4} \mathrm{CFU} / \mathrm{g}$ of dry soil. Means followed by the same letter are not significantly different at $P<0.05$. Each value is the mean of 15 replications from two experiments. Disease index (DI) was based on a scale of 0 to 3 , where $0=$ symptoms absent; $1=$ symptoms slight, may have small areas of chlorosis, transplant not stunted; $2=$ symptoms moderate, leaves yellowing, partial wilt of a couple of leaves, slightly stunted; and $3=$ complete wilt, all leaves affected, transplant severely stunted. DI was calculated using the following formula: DI $=$ $[\Sigma($ number of plants in each severity class $\times$ class number $)] \times 100 /($ mean number of plants grown in autoclaved soil $\times$ number of disease classes).

$38.4 \%$; whereas, in the experiment reported in Table 2, stand establishment was reduced to $8.8 \%$. These results suggest that, when disease pressure is very high, mycofumigation with $M$. roseus may be unsatisfactory with the formulations studied here. A similar trend was observed in the Aphanomyces experiments. At 14 days, mycofumigation with $M$. roseus stabileze formulation stand establishment was $53.6 \%$ but, after 21 days, stand establishment dropped to $30.4 \%$ and the ground barley formulation dropped from 34.4 to $20.4 \%$. In a different set of experiments comparing the stabileze formulation of $M$. roseus and $M$. albus, the percent emergence in the Aphanomyces treatment at 21 days was $13.6 \%$, the percent emergence in the $M$. roseus treatment was $29.6 \%$ (statistically equivalent), and the $M$. albus treatment was statistically higher at $45.6 \%$. These data suggest that $M$. albus mycofumigation is more effective on A. cochlioides and that $M$. roseus mycofumigation may leave enough oospores unaffected to produce sufficient inoculum after 3 weeks to cause severe disease. Experiments designed to test efficacy of $M$. roseus in relation to inoculum level could prove beneficial in explaining the inconsistencies in results reported here.

In experiments not reported here, it has been shown that neither $M$. albus nor $M$. roseus are pathogenic or phytotoxic to wheat, barley, chickpea, spotted knapweed, sugar beet, mint, potato, eggplant, or tomato $(25,26)$. Both endophytes are described as deuteromycetous (mycelia ster-

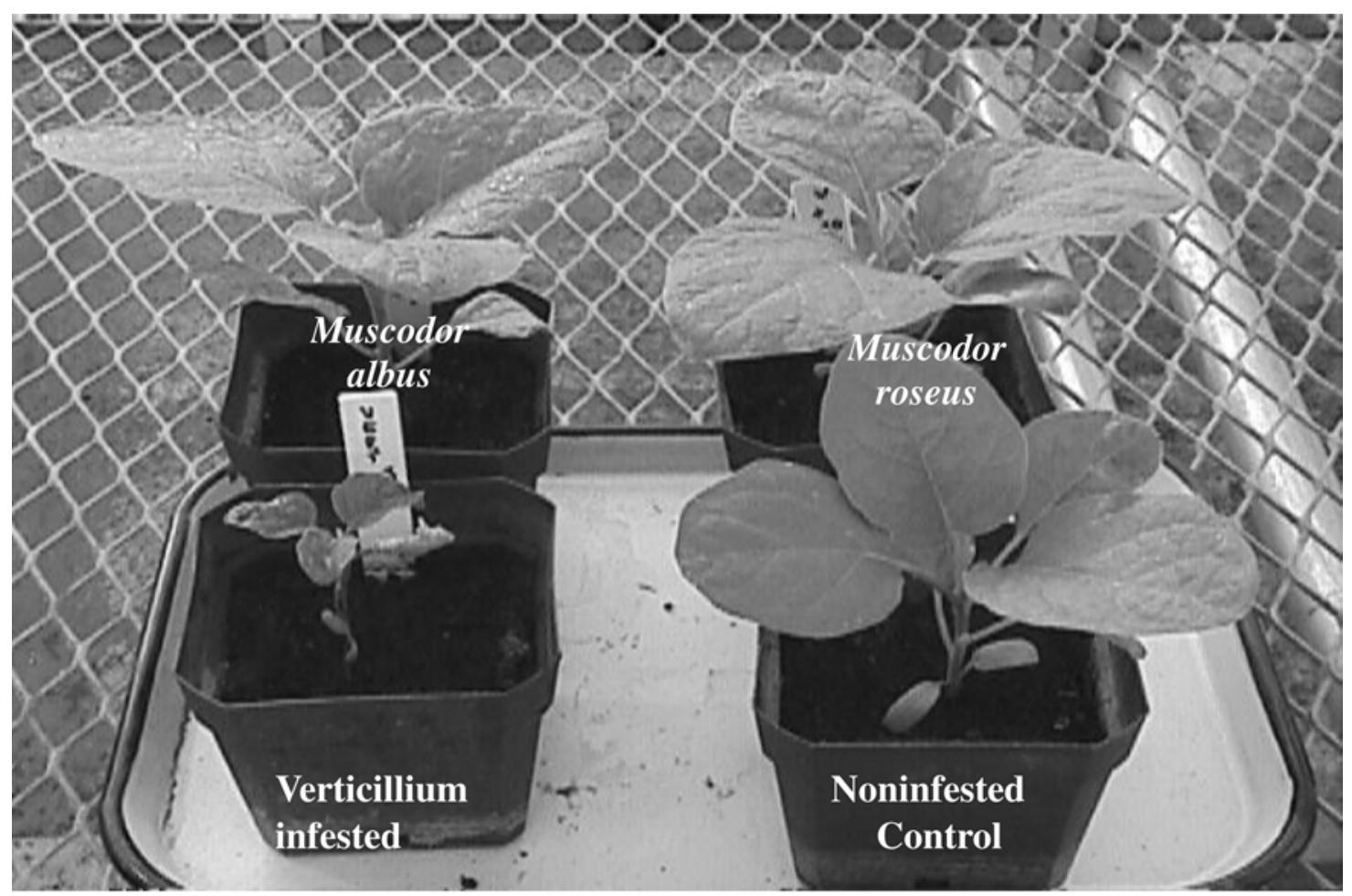

Fig. 1. Eggplant grown for 8 weeks in Verticillium dahliae-infested soil that had been mycofumigated for 1 week with Muscodor albus or M. roseus before planting compared with nonmycofumgated, V. dahliae-infested soil. 
ilia) $(23,24)$. The fact that neither fungus produces spores may limit unintended dispersal in the natural environment. It should be noted that mycofumigation with both fungi in the stabileze formulation did result in stunting of sugar beet seedlings and eggplant transplants. Mycofumigation with both fungi in the barley formulation did not result in growth differences, indicating that the reduced growth was a result of the stabileze formulation itself and not the fungi. However, the formulation alone was not tested. Perhaps the sucrose available in the stabileze formulation provided a substrate for bacteria or other microorganisms that acted like deleterious rhizobacteria that damage plants by producing hydrogen cyanide or other products deleterious to plant growth (10).

$M$. albus and $M$. roseus may offer an attractive alternative to $\mathrm{MBC}$ for multiple reasons. In 1998, the United States Department of Agriculture's IR-4 program began to identify chemical alternatives to methyl bromide for preplant soil fumigation in strawberries. Nelson et al. reported on various chemical treatments that gave yields as high or higher than those obtained with methyl bromide (15). However, the use of chemical alternatives still leaves growers vulnerable to future governmentmandated reductions in chemical use. Concomitantly, the number of registered pesticides, particularly for minor crops, is decreasing (10). In California, strict guidelines also limit applicability of available chemical alternatives: 1,3 dichlorpropene requires a 92-m buffer zone, and limits are placed on the amount that can be used in a township (12). Cost and application procedures also limit the use of chemical alternatives. The cost of dazomet is $\$ 2,793 /$ ha versus $\$ 2,117 /$ ha . for methyl bromide and requires an additional 2-week period between bed preparation and planting. In addition, dazomet must be tilled into the soil before bedding (18). Optimally, formulations of $M$. albus and $M$. roseus could be applied with existing farm equipment. Based on our work, the mycofumigant gases from both $M$. albus and $M$. roseus are not phytotoxic and would not require an interval between application and planting. Conversely, the lack of phytotoxicity also indicates that weed control would not occur. Another limitation is a lack of control of either root knot or sugar beet cyst nematode (B. J. Jacobsen, unpublished data). If commercialized, M. albus and $M$. roseus would be less likely to present health hazards to those in its proximity than other fumigant chemicals and would be subject to fewer limitations due to the fact that the volatiles are more selective in their toxicity (21).

Our results indicate that both $M$. roseus and $M$. albus reduce disease severity caused by $V$. dahliae (Table 3). M. albus mycofumigation significantly reduced population levels of $V$. dahliae. Because only 6 to 50 microsclerotia per gram are sufficient to give $100 \%$ infection in most susceptible crops (1), this level of control is not acceptable. However, we hypothesize that, if our initial inoculum had been more in the range of 10 to $50 \mathrm{CFU} / \mathrm{g}$, a parallel amount of reduction in inoculum level could result in undetectable levels of the pathogen. Experiments focusing on the mechanism of population reduction and on the effect of inoculum level need to be carried out before it can be speculated as to the efficacy of $M$. albus mycofumigation in the field.

Mycofumigation may present a less weather-dependent and more reliable alternative to solarization. This research shows that effective fumigation of the soil can occur at room temperature in the dark. Mycofumigation appears to be more practical than Brassica green manures, rotation crops, or seed meal amendments that have been reported to suppress pest and disease organisms when grown or incorporated in the soil $(3,13)$. Bianco et. al. (2) quantified isothiocyanates produced by the freezedried roots of Indian mustard (Brassica juncea) and a turnip-canola mix (B. campestris and $B$. napus) before and after their incorporation into a light clay loam. They demonstrated that isothiocyanates were recovered at lower concentrations from roots incorporated into the soil. These levels were at least 15 times below those required to control most pest and pathogens based on commercial fumigant levels (2). In experiments testing the effects of combining solarization and biofumigation on populations of Phytophthora, no additional benefit was observed where cabbage residue was incorporated into the soil (5).

The results presented in this article suggest that formulations differentially influence mycofumigation efficacy; therefore, it is possible to maximize mycofumigation efficacy of both $M$. roseus and $M$. albus in the soil by selecting an appropriate formulation. M. albus in the stabileze formulation repeatedly reduced disease severity and populations of $V$. dahliae, indicating that an effective level of volatile antimicrobials is produced consistently in vivo in this formulation. However, the stabileze formulation did cause stunting of plants. Currently, research is underway to determine the optimal formulation of $M$. albus for field trials and to determine whether the effects observed in autoclaved, artificially pathogeninfested soil occur under field conditions. An attractive advantage of mycofumigation with $M$. albus and $M$. roseus is the ability to control disease severity caused by a variety of plant pathogens of various fungal classes. Pathogen inoculum density, however, appears to heavily influence the degree to which the disease is controlled by current mycofumigation formulations and dosages.
ACKNOWLEDGMENTS

We thank M. L. Spang and A. V. Bird for their assistance in this research.

\section{LITERATURE CITED}

1. Agrios, G. N. 1997. Plant Pathology. 4th ed. Hartcourt Academic Press, Burlington MA.

2. Bianco, V., Nicholls, J., Mattner, S., Allen, D. and Porter, I. 2000. Biofumigation in Australian horticulture: an integrated approach to MB replacement. Methyl Bromide Phaseout-Proc. 2000 Alternatives Res. Conf. p 18-1 to 14.

3. Chan, M. K. Y., and Close, R. C. 1987. Aphanomyces root-rot of peas. 3. Control by use of cruciferous amendments. N. Z. J. Agric. Res. 30:225-233.

4. Chandler, C. K., Legard, D. E., and Noling J. W. 2001. Performance of strawberry cultivars on fumigated and nonfumigated soil in Florida. HortTechnology 11:69-71.

5. Coelho, L., Chellemi, D. O., and Mitchell, D. J. 1999. Efficacy of solarization and cabbage amendment for the control of Phytophthora spp. in North Florida. Plant Dis. 83:293-299.

6. Connick, W. J., Jr., Boyette, C. D., and McAlpine, J. R. 1991. Formulations of mycoherbicides using a pasta-like process. Biol. Control 1:281-287.

7. Dennis, C., and Webster, J. 1971. Antagonistic properties of species-groups of Tricho derma. II. Production of volatile antibiotics. Trans. Br. Mycol. Soc. 57:41-48.

8. Duniway, J. M., Haoa, J. J., Dopkinsa, D. M., Ajwab, H., and Brownec, G. T. 2000. Some chemical, cultural and biological alternatives to methyl bromide fumigation of soil for strawberry. Methyl Bromide Phaseout-Proc 2000 Alternatives Res. Conf. p. 9-1 to 2.

9. Hoitink, A. A. J., and Boehm, M. J. 1999 Biocontrol within the context of soil microbial communities: a substrate dependent phenomenon. Annu. Rev. Phytopathol. 37:427446.

10. Jacobsen, B. J., and Backman, A. 1993. Biological and Cultural plant disease controls: alternatives to chemicals in IPM systems. Plant Dis. 77:311-315.

11. Korolev, N., and Katan, T. 1997. Improved medium for selecting nitrate-nonutilizing (nit) mutants of Verticillium dahliae. Phytopathology 87:1067-1070.

12. Martinez, C., Fennimore, S., and Husein, A. Strawberry production with methyl bromide alternatives: a farmer's perspective. Methyl Bromide Phaseout-Proc. 2000 Alternatives Res. Conf.

13. Mojtahedi, H. Santo, G. S., Hang, A. N., and Wilson, J. H. 1991. Suppression of root-knot nematode populations with selected rapeseed cultivars as green manure. J. Nematol. 23:170-174.

14. Nash, S. M., and Snyder, W. C. 1962. Quantitative estimations by plate counts of propagules of the bean root rot Fusarium in field soils. Phytopathology 51:308-312.

15. Nelson, M., and Olsen, B. Results from 1999 2000 USDA IR-4 MBA field trials in CA and FL strawberries. 2000. Methyl Bromide Phaseout-Proc. 2000 Alternatives Res. Conf. p. 3-1 to 4 .

16. Pierson, V. G., and Gaskill, J. O. 1961. Artificial exposure of sugar beets to Rhizoctonia solani. J. Am. Soc. Sugar Beet Technol. 19:246-256.

17. Quimby, P. C., Jr., Zidack, N. K., Boyette, C. D., and Grey, W. E. 1999. A simple method for stabilizing and granulating fungi. Biocontrol Sci. Technol. 9:5-8.

18. Reiger, M., Krewer, G., and Lewis, P. 2001 Solarization and chemical alternatives to methyl bromide for preplant soil treatment of strawberries. HortTechnology 11(2):258-264. 
19. Ruppel, E. G., Schneider, C. L., Hecker, R. J., and Hogaboam, G. J. 1979. Creating epiphytotics of Rhizoctonia root rot and evaluating for resistance to Rhizoctonia solani in sugarbeet field plots. Plant Dis. Rep. 63:518-522.

20. Sarwar, M., and Kirkegaard, J. A. Biofumigation potential of brassicas. II. Effect of environment and ontogeny on glucosinolate production and implications for screening. 1998. Plant Soil 201:91-101.

21. Strobel, G. A., Dirske, E., Sears, J., and Markworth, C. 2001. Volatile antimicrobials from Muscodor albus, a novel endophytic fungus. Microbiology 147:2943-2950.

22. Walker, H. L., and Connick, W. J., Jr. 1983.
Sodium alginate for production and formulation of mycoherbicides. Weed Sci. 31:333338.

23. Worapong, J., Strobel, G. A., Daisy, B. H., Castillo, U., Baird, G., and Hess, W. M. 2001. Muscodor roseus sp. nov., an endophyte from Grevillea pteridifolia. Mycotaxon 81:463475

24. Worapong, J., Strobel, G. A., Ford, E., Li, J. Y., Baird, G., and Hess, W. M. 2001. Muscodor albus anam. gen. et sp. nov., an endophyte from Cinnamomum zeylanicum. Mycotaxon 79:67-69.

25. Zidack, N. K., Grimme, E., Ezra, D., Stinson, A. M., Srobel, G. A., and Jacobsen, B. J.
2002. Progress in the development of mycofumigation for control of soil-borne plan diseases. Pages 38-42 in: Proc. 2002 Annu. Int. Conf. Methyl Bromide Alternatives Emissions Reductions. USEPA/USDA, Washington, DC.

26. Zidack, N. K., Jacobsen, B. J., Stinson, A. M. and Strobel, G. A. 2001. Mycofumigation: A novel alternative to methyl bromide. Pages 36-1 in: Proc. 2001 Annu. Int. Conf. Methyl Bromide Alternatives Emissions Reductions. USEPA/USDA, Washington, DC

27. www.epa.gov/spdpublc/mbr. Official Environmental Protection Agency methyl bromide information website. 